\title{
De novo design of selective compounds: a fragment-based pipeline applied to the $\beta 2$ adrenergic receptor
}

Florent Chevillard*, Peter Kolb

From 9th German Conference on Chemoinformatics

Fulda, Germany. 10-12 November 2013

GPCRs play a key role in transmembrane signaling and are involved in many physiological processes, such as regulation of behavior, heart rate and the immune system. Therefore they are very important targets for pharmaceutical agents. Our project focuses on the $\beta_{2}$ Adrenergic Receptor [1,2] ( $\left.\beta_{2} \mathrm{AR}\right)$. The $\beta_{2} \mathrm{AR}$ is mainly involved in vasodilation and bronchodilation in the human body. The recently solved structures of the $\beta_{2} \mathrm{AR}$ open up new possibilities in the design of novel specific ligands using structure-based approaches. Here, we describe a pipeline to grow an unspecific fragment-sized scaffold for the $\beta_{2} \mathrm{AR}$. The protocol uses focused docking of fragments in two different zones identified within the binding site. The top ranked fragments are then computationally added to the core scaffold, filtered, minimized, evaluated by flexible ligand docking and inspected for later synthesis. Our initial results show that promising ligands can be identified by adding discriminating fragments to a core scaffold and that the generated compounds provide a reasonable synthetic accessibility.

Published: 11 March 2014

\section{References}

1. Cherezov V, Rosenbaum DM, Hanson MA, Rasmussen SGF, Thian FS, Kobilka TS, Choi H-J, Kuhn P, Weis WI, Kobilka BK, Stevens RC: HighResolution Crystal Structure of an Engineered Human 2-Adrenergic G Protein Coupled Receptor. Science 2007, 318:1258-1265.

2. Rosenbaum DM, Cherezov V, Hanson MA, Rasmussen SGF, Thian FS, Kobilka TS, Choi H-J, Yao X-J, Weis WI, Stevens RC, Kobilka BK: GPCR Engineering Yields High-Resolution Structural Insights into 2-Adrenergic Receptor Function. Science 2007, 318:1266-1273.

* Correspondence: florent.chevillard@uni-marburg.de Kolblab, Institute of Pharmaceutical Chemistry, Philipps-University Marburg, Marbacher Weg 6-10, 35037 Marburg, Germany

(c) 2014 Chevillard and Kolb; licensee Chemistry Central Ltd. This is an Open Access article distributed under the terms of the Creative Commons Attribution License (http://creativecommons.org/licenses/by/2.0), which permits unrestricted use, distribution, and reproduction in any medium, provided the original work is properly cited. The Creative Commons Public Domain Dedication waiver (http://creativecommons.org/publicdomain/zero/1.0/) applies to the data made available in this article, unless otherwise stated.
doi:10.1186/1758-2946-6-S1-P25

Cite this article as: Chevillard and Kolb: De novo design of selective compounds: a fragment-based pipeline applied to the $\beta 2$ adrenergic receptor. Journal of Cheminformatics 2014 6(Suppl 1):P25.
Publish with ChemistryCentral and every scientist can read your work free of charge

"Open access provides opportunities to our colleagues in other parts of the globe, by allowing anyone to view the content free of charge."

W. Jeffery Hurst, The Hershey Company.

- available free of charge to the entire scientific community

- peer reviewed and published immediately upon acceptance

- cited in PubMed and archived on PubMed Central

- yours - you keep the copyright

Submit your manuscript here:

http://www.chemistrycentral.com/manuscript/ 